\title{
Drought resistance and gum yield performances in a Senegalia senegal (L.) Britton progeny trial in Senegal
}

\author{
Mame S. Sarr ${ }^{1}$ D . John R. Seiler ${ }^{2} \cdot$ Jay Sullivan $^{2} \cdot$ Adja M. Diallo $^{1} \cdot$ Brian D. Strahm² $^{2}$
}

Received: 25 June 2020 / Accepted: 8 December 2020 / Published online: 18 January 2021

(c) The Author(s) 2021

\begin{abstract}
With continued global change as a result of land use changes, invasive species and changing climatic patterns, it is becoming increasingly important to understand the adaptability of Senegalia senegal provenances to maximize resilience in managed and natural populations of this species. The objective of this study is to investigate Senegalia senegal genotypic differences in water use efficiency (WUE) measured by stable ${ }^{13} \mathrm{C}$ isotope composition in foliage according to their ploidy levels. Secondary objectives are to discuss inherent adaptive variation related to soil $\mathrm{pH}$, survival, growth indexes, gum arabic yield and WUE within provenance in the climate change context. A Senegalia senegal progeny trial, in Dahra, Senegal was used in this study: 443 adult trees consisting of 60 families nested within 4 provenances were assessed in this study. Results showed significant differences in gum yield among provenances $(P=0.0002)$ and families $(P<0.0001)$. Diamenar and Ngane provenances showed overall similar annual gum yield despite a lower tree survival rate of Ngane than Diamenar. Growth traits, especially stem volume index and crown area index were larger on Ngane provenance, which also displayed significantly higher foliar WUE and lower leaf area index (LAI) than the other provenances. WUE was positively correlated with gum yield $(P=0.0302)$, but the coefficient of determination was only $2 \%$. Foliar $\delta^{13} \mathrm{C}$ varied significantly $(P<0.0001)$ between diploids $(-27.91 \%)$ and polyploids $(-27.12 \%$ o). However, within each provenance no significant difference was found. Only $15 \%$ of isotope compositions could be explained by ploidy level variation. Differences found in growth and gum yield may be attributed to genotype-specific variation. However, a significant correlation between soil $\mathrm{pH}$ and tree survival rate was found $(P=0.0051$; $\mathrm{r}=0.60$ ). This study confirmed a possible improvement of the gum arabic sector through genotype based selection. Ngane and Diamenar seem to be more profitable to grow in Dahra than the other tested provenances. Future research should investigate the effect of soil $\mathrm{pH}$, other soil physical and chemical properties, and management activities to improve site quality on tree survival and gum yields among provenances. Further, more research is needed to clarify inherent traits underlying drought tolerance in the field and gum yield performance.
\end{abstract}

Keywords Provenances $\cdot$ Gum Arabic $\cdot$ WUE $\cdot \delta^{13} \mathrm{C}$ analysis $\cdot$ Ploidy $\cdot$ Drought

Mame S. Sarr

mame13@vt.edu

Extended author information available on the last page of the article 


\section{Introduction}

Gum arabic from Senegalia senegal is a valuable non-timber forest product, and it represents a substantial component of household income for many local communities in Africa and particularly in the Sahel (Barbier 1992; Chikamai and Odera 2002; Bradley and Grainger 2004; Wekesa et al. 2010; Mujawamariya and D’Haese 2012). However, gum production fluctuates and is affected by abiotic environmental factors and associated changes in plant physiology, which make estimation of gum yield uncertain. Sudan is the biggest gum producer, but Senegal's gum is internationally recognized for being of best quality despite low production potential accounting for less than five percent of the world market (Mujawamariya et al. 2012). Gum supplies from Senegal declined especially following periods of drought in the 1970s and 1980s which had decreased the density of woody cover in the northern ecoregions in Senegal, the natural growing areas of Senegalia senegal (Poupon 1976; Lawesson 1995; Gonzalez 1997). Many tree plantation programs targeting drylands and livelihood restorations developed following this time. And in that context, Institut Sénégalais de Recherche Agricole developed seed orchards and provenance/progeny tests to support plantation operations and develop a deep understanding of challenges underlining gum yield variabilities. This current study is among those field trials-based-research carried out to construct basis of the rehabilitation of gum arabic sector improvement in Senegal.

Because of severe and frequent drought occurrences, optimizing gum arabic production requires consideration of indicators of adaptability such as survival, growth, and water use efficiency (WUE). Integrated WUE refers to total carbon gain to total water loss of a leaf, plant or ecosystem and often relates to growth performance in drought adapted species. Correlation between integrated WUE and stable ${ }^{13} \mathrm{C}$ isotope discrimination provides a simplified measurement of WUE. ${ }^{13} \mathrm{C}$ isotope analysis has become a valuable tool in plant ecophysiology to help understand the link between photosynthesis and water use of plant species (Farquhar et al. 1989). It may be used as a criterion for ecotype selection for improved WUE in trees (Farquhar et al. 1989) and possibly in gum yield from Senegalia senegal. Recently, it was revealed that high gum yield is associated with low water use efficiency from isotope analysis whereas higher WUE is usually positively correlated with drought resistance (Raddad and Luukkanen 2006; Bacelar et al. 2007; Rivero et al. 2007; Gray et al. 2013). Therefore, it may be useful to examine the relationship between WUE and gum Arabic yield in this study especially since research in that line is very limited.

It is also important to understand the pattern of basic genetic variation underlying drought adaptability and gum yield performance in this important species. Early provenance studies attributed gum yield variability to the location of provenance, with trees originating from wetter areas producing more gum (Raddad et al. 2006; Harmand et al. 2012). However, patterns of gum yield variability mainly occurred within rather than between populations (Josiah et al. 2008; Harmand et al. 2012; Gray et al. 2013). Therefore, a better understanding of the genetic and environmental factors influencing gum yield is still needed to improve gum productivity. A recent study by Diallo et al. (2015) carried out in a progeny trial in Dahra, Senegal, revealed that Senegalia senegal genetic parameters differ according to the ploidy level. Ngane was reported predominantly tetraploid and has been implicated with a higher drought resistance performance than the diploid relatives in the seedling stage. This finding led us to investigate the relationship between ploidy level and WUE of adult Senegalia senegal trees. Polyploidy enhances gene expression on a plant's ability to survive harsh environmental conditions such as water stress (Maherali 
et al. 2009; Segraves and Anneberg 2016; Greer et al. 2017). Therefore, it is likely that a relationship between ploidy levels and foliar $\delta^{13} \mathrm{C}$ exists in gum arabic trees. This information will be useful in tree breeding of Senegalia Senegal trees. The objectives of this study are to 1) discuss inherent adaptive variation related to survival, soil $\mathrm{pH}$, growth indexes, gum yield and WUE within provenances of Senegalia senegal, and 2) investigate genotypic differences in WUE measured by stable ${ }^{13} \mathrm{C}$ isotope composition in foliage accordingly to their ploidy levels. We hypothesized that polyploidy increases water use efficiency in Senegalia senegal.

\section{Materials and methods}

\section{Site description and trial setup}

The field experiment was conducted in a Senegalia senegal progeny trial established in 1994 in Dahra, Senegal (15 35 N, 15 43 W, 43.2 m altitude) at the Centre de Recherches Zootechniques of Institut Sénégalais de Recherche Agricole. The climate in Dahra is subtropical, hot semi-arid, with mean annual rainfall over 10 years (2006-2015) of $398.3 \mathrm{~mm}$. The monthly average temperature varies between $19{ }^{\circ} \mathrm{C}$ in January to $41^{\circ} \mathrm{C}$ in May. Soil is sandy dune, type arenosol covered with $96 \%$ sand/grass and $4 \%$ trees (Brandt et al. 2014; Göttsche et al. 2016). Provenances in the study are all originally selected from the natural range of the species in Senegal (Fig. 1). The provenance Diamenar is located in the sylvopastoral area of Senegal with $284 \mathrm{~mm}$ of rainfall. Kidira and Daiba provenances are in the eastern part with $505 \mathrm{~mm}$ of rainfall and in north-eastern Senegal with $458 \mathrm{~mm}$ of rainfall,

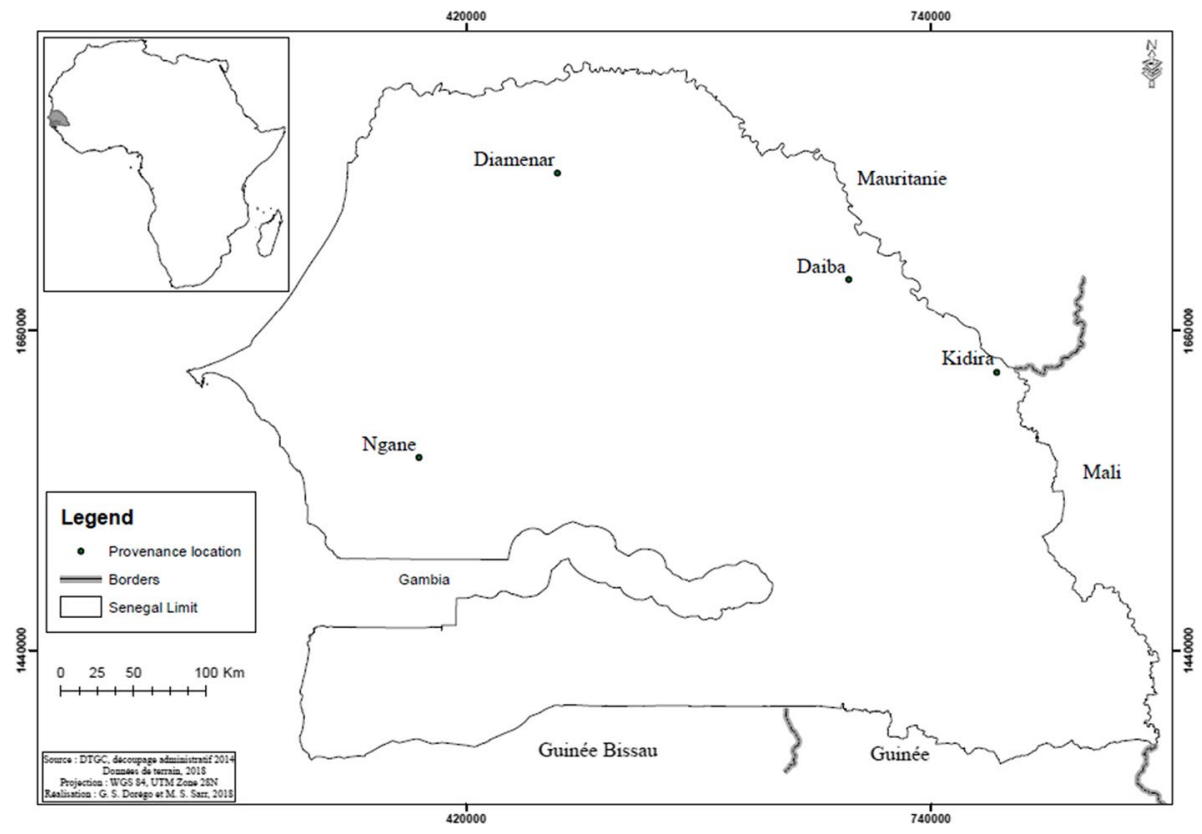

Fig. 1 Location of the four Senegalia senegal provenances in Senegal 
respectively. Ngane provenance is located in the groundnut basin of Senegal characterized by saline soil and $712 \mathrm{~mm}$ of rainfall. At each provenance site, open-pollinated seeds were collected from 15 to 30 dominant trees located at least 100 meters from each other. For each provenance, 15 different mother trees (families) were randomly assigned to a singletree plot in each replication. Seeds were germinated and raised in the nursery of Centre National de Recherche Forestière for 4 months. Seedlings were planted in Dahra in August 1994 in a randomized complete block design with 30 blocks as replications. Each block contains 60 trees (15 trees per provenance) planted at a 5-meter spacing. Because of site size constraints, twenty replications were located contiguously and an additional 10 were broken into smaller locations nearby. To minimize effects of site heterogeneity, for this study we only used the twenty replications from the contiguously located blocks, which initially include a total of 1200 trees. There was a border row around the contiguous block of replications. The trial has been used to test for genetic assessment (Diallo 1994; Diallo et al. 2015, 2016), but this current study will be the first experiment involving ${ }^{13} \mathrm{C}$ isotope composition analysis and soil characteristics and their relationship with tree ploidy, survival, gum arabic yield and growth.

\section{Tapping treatment and gum harvest}

We harvested gum yield by tree during the periods 2014/2015 and 2015/2016. The standard tapping method used on Senegalia senegal trees in Senegal was performed in order to induce gum exudation from stems and branches. This consisted of removing a portion ( $4 \mathrm{~cm}$ wide and $30 \mathrm{~cm}$ to $1 \mathrm{~m}$ long) of the bark of stems and branches with a special tool called a "Daba" (Harmand et al. 2012). Tapping was initiated between October and November when trees began dropping their foliage as recommended by and Dione and Vassal (1998) and Adam et al. (2013). The first gum collection occurred 3 weeks after tapping and then three other collections followed every 3 to 4 weeks. Gum was manually harvested then air dried for several days and weighed. Gum yield is the average per plant along with the bark portion removed from stems and branches of each tree. Gum harvest assessed in this study was a follow up of the 2 previous years already assessed by Diallo et al. (2015).

\section{Growth characteristics, survival rate and leaf area index measurements}

Tree height, diameter, crown width, and leaf area index were measured for each tree in October 2015. At the same time, foliage was collected for ${ }^{13} \mathrm{C}$ analyses. Since Senegalia senegal usually presents co-dominant stems from near the base and several bifurcations at relatively low height, diameters in this study were measured at $0.5 \mathrm{~m}$ from the ground with a laser caliper. The crown width was the average of the crown diameter in two perpendicular directions. We used a basal area weighted mean diameter $\left(D_{w}\right)$ to estimate tree stem volume index $\left(\mathrm{D}_{\mathrm{w}}\right.$ squared $\times$ height $)$. The weighted mean diameter was computed by using the following equation:

$$
\mathrm{D}_{\mathrm{w}}=\sum_{i=1}^{n} \frac{w_{i} d_{i}^{3}}{w_{i} d_{i}^{2}} \text { (Husch et al. 2003). }
$$


where $\mathrm{n}$ is the number of tree stems, $\mathrm{w}_{\mathrm{i}}$ is the tree expansion factor, and $\mathrm{d}_{\mathrm{i}}$ the diameter at $50 \mathrm{~cm}$.

The projected crown areas at height $\mathrm{h}$ from the ground to the top of the canopy was determined and expressed as crown area index (height $\times$ crown width). Survival for each source was determined by dividing the number of living trees over the number of trees originally planted. Leaf area index (LAI), the amount of one-sided leaf area per unit area of ground, was measured with a LAI-2200 plant canopy analyzer (PCA, Li-Cor, Inc., Lincoln, $\mathrm{NE}$ ). Readings were taken under uniform light conditions, using the one sensor mode with a $45^{\circ}$ view cap. We conducted 5 readings under each tree canopy coupled with one reading outside the tree canopy.

\section{Carbon isotope composition $\left(\delta^{13} \mathrm{C}\right)$ analysis}

Carbon isotope analysis was conducted in the laboratory of the Department of Forest Resources and Environmental Conservation, Virginia Tech, Virginia, USA. From each Senegalia senegal tree, green mature leaves were collected from the four corners of each tree to form a composite foliage sample. Leaf collection was completed in late October. A total of 443 composite leaf samples were collected and quickly air dried and then transported to Virginia Tech and stored in an oven at $65^{\circ} \mathrm{C}$. Dried leaf samples were ground with a ball mill, placed in clean tin capsules and weighed on an electronic balance (Mettler Toledo XP6, Columbus, OH, USA), and loaded into an automatic sampler. An elemental analyzer continuous flow stable isotope ratio mass spectrometer (IsoPrime100, Isoprime Ltd., UK) was used to determine the carbon isotope ratio ${ }^{13} \mathrm{C} /{ }^{12} \mathrm{C}$. The $\delta{ }^{13} \mathrm{C}$ values were expressed relative to the Pee Dee Belemnite international standards (Craig 1953; Farquhar et al. 1989).

\section{Soil pH and electrical conductivity}

Electrical conductivity and soil $\mathrm{pH}$ were assessed both under each tree canopy and in each block. For each tree, we collected 5 randomly selected sub-samples under the canopy to form one mixed composite sample. In each block, we sampled 5 points randomly selected under or outside tree canopies. Each sampled point per block consisted of 6 randomly selected sub-samples to form a single composite sample.

Each sample consisted of collecting soil to a $10 \mathrm{~cm}$ depth. EC and $\mathrm{pH}$ analysis were conducted in a 1:1 soil/distilled water mixture for each sample. The electrical conductivity (EC) was measured with a multi parameter analyzer (Consort C535, Dorval, Quebec, Canada) and the $\mathrm{pH}$ with a microprocessor $\mathrm{pH}$ meter (HI 223, Hanna instruments, Woonsocket, RI, USA).

\section{Experimental design and data analysis}

The experimental layout was a nested design with 20 replications. We used variance components methods to perform analysis of variance. Family was nested within provenance and each tree was used as the experimental unit. To determine whether there was greater variation among provenances than families, variance components were derived considering family and provenance as random variables. The Restricted Maximum Likelihood method was used to estimate the variance components. Data were subjected to an unbalanced 
analysis of variance due to the different survival rates among seed sources (provenance) and blocks. However, due to the complexity of estimating variance components for an unbalanced design, we used a partially balance data (Khattree and Naik 1990; Searle et al. 1992).

We also performed analyses of variance. For stem volume index, gum yield and crown area index, we used a Box-Cox power transformation with the following equation: $\mathrm{Y}_{\lambda}=\{(\overline{\mathrm{y}}-1) / \lambda$ if $\lambda \neq 0$ or $\ln (\mathrm{Y})$ if $\lambda=0)$ to improve normality and constant variance. For each variable, we used the option "save best transformation" on JMP which gives the best $\lambda$ value. Outliers were identified and removed for the electrical conductivity and $\delta^{13} \mathrm{C}$ datasets. Differences in least squares means were assessed at $P<0.05$ using Tukey Honestly Significant Difference test and Wilcoxon for survival rate. Due to the relative high number of families, we performed means comparison by using five best and five worse families for each variable. Simple linear regression analysis was performed between gum yield and each of the other measured variables. A zero was recorded for each tree which did not produce gum. All statistical analyses were performed using JMP 12 software (SAS Institute, Cary, NC, USA). The following model was used for the analysis of variance:

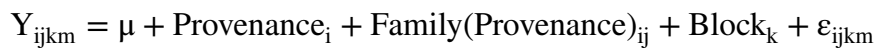

where $Y_{i j k m}$ is the value of the variable in question; $\mu$ is the true mean; Provenance ${ }_{i}$ is the fixed effect of provenance number $\mathrm{i}(\mathrm{i}=1 \ldots .4)$; Family(Provenance $)_{\mathrm{ij}}$ is the effect of family number $\mathrm{j}(\mathrm{j}=1 \ldots \ldots .15)$ nested within provenance ${ }_{\mathrm{j}}$; Block $_{\mathrm{k}}$ is the replication number $\mathrm{k}$ $(\mathrm{k}=1 \ldots 20) \varepsilon=$ deviation associated with each observation.

The ploidy level of each tree was determined by Diallo et al. (2015). We conducted an analysis of variance of foliar $\delta^{13} \mathrm{C}$ between diploids and polyploids in which provenance is disregarded. Then, we conducted an analysis where ploidy was nested within provenance.

\section{Results}

\section{Sources of variation on assessed traits}

For most variables, the variance was mostly attributed to the error term (Table 1). However, for foliar ${ }^{13} \mathrm{C}$ provenance explained $32.7 \%$ of the variance (Table 1). Low variation

Table 1 Overall means, variance components $(\%)$ and residual variance for Senegalia senegal variables assessed in the study

\begin{tabular}{llrlll}
\hline Variable & Overall mean & \multicolumn{3}{l}{$\begin{array}{l}\text { Variance components in } \% \\
\text { (degrees of freedom) }\end{array}$} \\
\cline { 2 - 6 } & & $\sigma_{\mathrm{p}}^{2}(3)$ & $\sigma_{\mathrm{f}(\mathrm{p})}^{2}(56)$ & $\sigma_{\mathrm{B}}^{2}(2)$ & $\sigma_{\mathrm{e}}^{2}(120)$ \\
\hline Survival & $36.9 \%$ & 2.1 & 5.6 & 3.0 & 89.3 \\
Foliar ${ }^{13} \mathrm{C}$ & -27.68 & 32.7 & 9.3 & 11.5 & 46.5 \\
Leaf Area Index & 1.11 & 4.8 & 4.3 & 42.3 & 48.7 \\
Gum yield & $453.7 \mathrm{~g}$ & 5.7 & 9.6 & 3.0 & 81.7 \\
Stem volume index & $12.85 \mathrm{dm}^{3}$ & 10.6 & 5.9 & 3.5 & 80.0 \\
Crown area index & $26.59 \mathrm{~m}^{2}$ & 3.7 & 10.4 & 4.1 & 81.8 \\
\hline
\end{tabular}

$\sigma_{\mathrm{p}}^{2}$ is the variance among provenance; $\sigma_{\mathrm{f}(\mathrm{p})}^{2}$ is the variance among families within provenance; $\sigma_{\mathrm{B}}^{2}$ is the variation allocated to replication; $\sigma_{\mathrm{e}}^{2}$ is the error term 
Table 2 Survival rate, leaf area index, stem volume index and crown area index, ${ }^{13} \mathrm{C}$ composition, and gum Arabic yield among provenances of a 20 -year-old Senegalia senegal progeny test

\begin{tabular}{lccrr}
\hline Variable & \multicolumn{1}{l}{ Daiba } & \multicolumn{1}{l}{ Diamenar } & \multicolumn{1}{l}{ Kidira } & \multicolumn{1}{l}{ Ngane } \\
\hline Survival rate $(\%)$ & $39 \pm 0.03 \mathrm{ab}$ & $46.67 \pm 0.03 \mathrm{a}$ & $27.67 \pm 0.03 \mathrm{c}$ & $34 \pm 0.03 \mathrm{bc}$ \\
Leaf area index & $1.13 \pm 0.06 \mathrm{a}$ & $1.23 \pm 0.05 \mathrm{a}$ & $1.04 \pm 0.06 \mathrm{ab}$ & $0.96 \pm 0.05 \mathrm{~b}$ \\
Stem volume index $\left(\mathrm{m}^{3}\right)$ & $8.73 \pm 1.5 \mathrm{c}$ & $11.76 \pm 1.36 \mathrm{~b}$ & $11.08 \pm 1.83 \mathrm{bc}$ & $21.20 \pm 1.58 \mathrm{a}$ \\
Crown Area index $\left(\mathrm{m}^{2}\right)$ & $24.24 \pm 0.85 \mathrm{c}$ & $25.50 \pm 0.76 \mathrm{bc}$ & $27.72 \pm 1.01 \mathrm{ab}$ & $29.21 \pm 0.89 \mathrm{a}$ \\
${ }^{13} \mathrm{C}(\% \mathrm{c})$ & $-28.01 \pm 0.09 \mathrm{~b}$ & $-27.86 \pm 0.07 \mathrm{~b}$ & $-27.85 \pm 0.10 \mathrm{~b}$ & $-27.03 \pm 0.09 \mathrm{a}$ \\
Gum yield $(\mathrm{g})$ & $329.51 \pm 41.92 \mathrm{~b}$ & $456.48 \pm 40.98 \mathrm{a}$ & $457.19 \pm 6.77 \mathrm{a}$ & $567.63 \pm 40.99 \mathrm{a}$ \\
\hline
\end{tabular}

For each variable, means followed by the same letter are not significantly different at $P<0.05$

Fig. 2 Soil pH versus 20-year-old Senegalia senegal tree survival in each block in Dahra Senegal

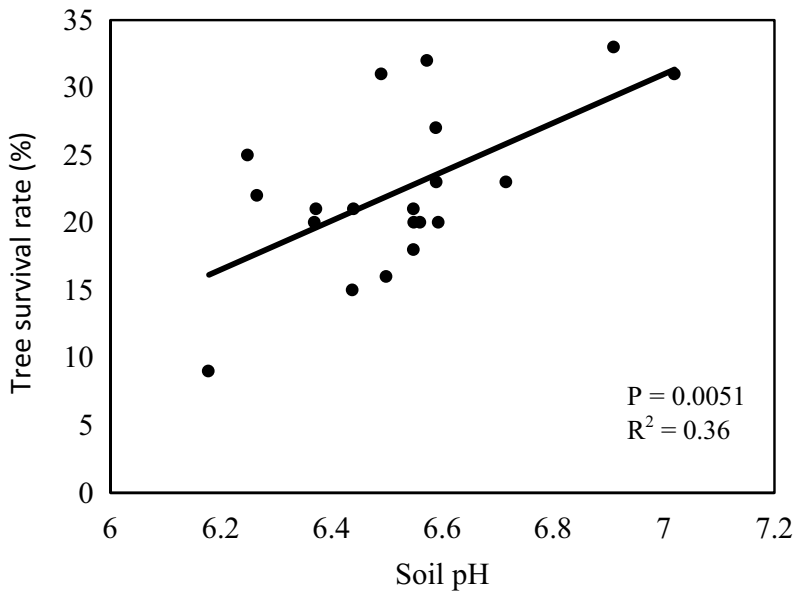

(less than 5\%) was attributed to block effect except for ${ }^{13} \mathrm{C}(11.5 \%)$ and leaf area index $(42.3 \%)$.

\section{Tree survival rate, soil pH, and electrical conductivity}

The binomial analysis of variance of tree survival rates revealed significant differences among provenances $(P<0.0001)$ and families $(P<0.0001)$. Tree survival rate varied between $46.7 \%$ for Diamenar to $27.7 \%$ for Kidira with an overall mean survival estimated at $36.9 \%$ (Table 2). Some of the lowest survivals were in families K7, K23, Da4, Ng 11 and K25 (10\% or less). Da8 had the highest survival (85\%) (Fig. 3a). There was a significant positive correlation $(P=0.0051, \mathrm{r}=0.60)$ between average block tree survival and average block soil pH (Fig. 2). No significant family or provenance differences was found for soil electrical conductivity and soil $\mathrm{pH}$ under tree canopies. 

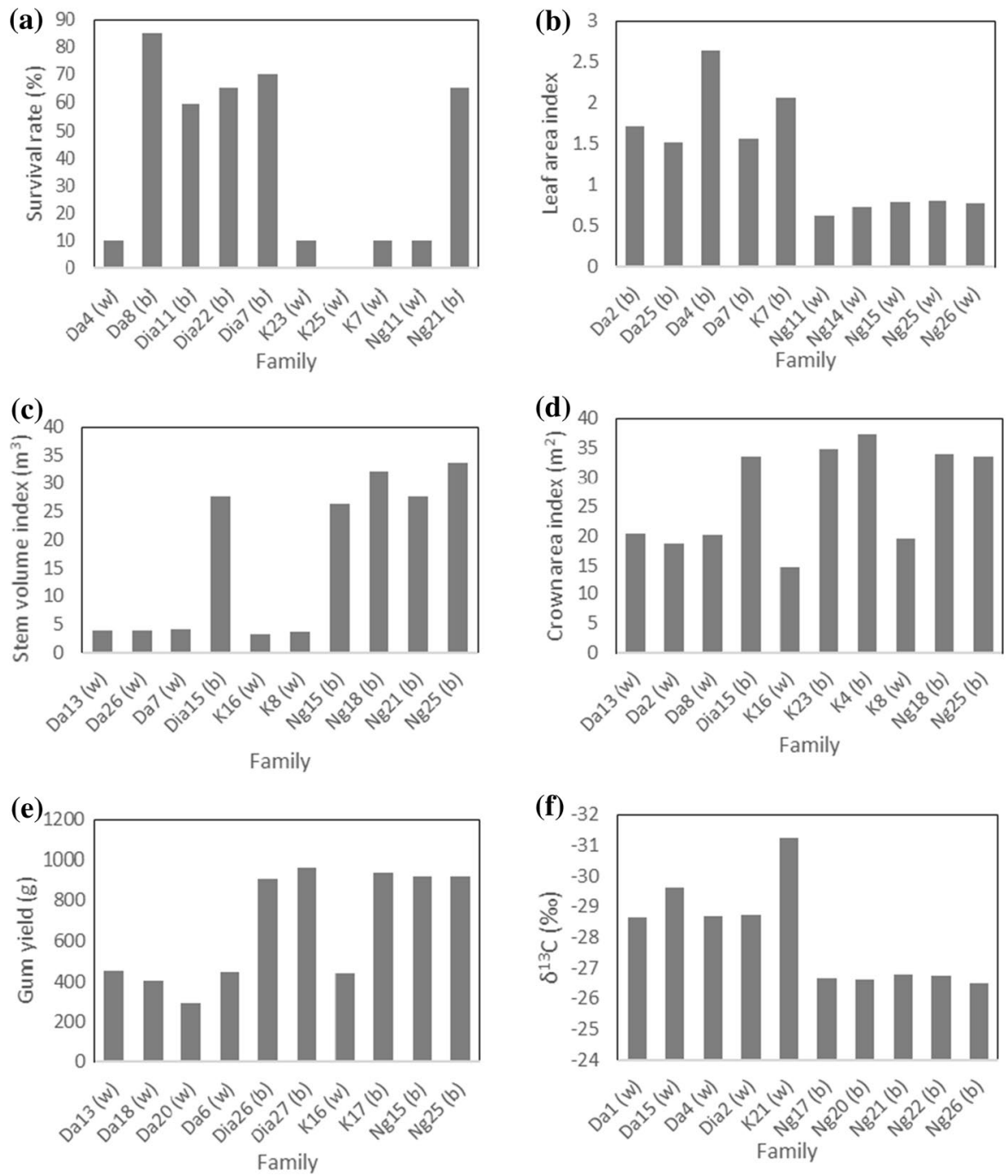

Fig. 3 Survival rate (a), leaf area index (b), stem volume index (c), crown area index (d), gum arabic yield (e) and carbon isotope composition (f) of the 5 best(b) and 5 worse(w) families in a 20-year-old Senegalia senegal progeny trial in Dahra, Senegal

\section{Variation of stem volume index, crown area index and leaf area index}

Ngane had the lowest LAI (0.96) but by far the greatest stem volume index $\left(21.2 \mathrm{dm}^{3}\right)$ which was nearly double Diamenar $\left(11.8 \mathrm{dm}^{3}\right)$ the next largest. Daiba had the lowest stem volume index $\left(8.7 \mathrm{dm}^{3}\right)$ (Table 2). Crown area index was also greatest for Ngane provenance $\left(29.2 \mathrm{~m}^{2}\right)$ and Daiba again had the lowest $\left(24.2 \mathrm{~m}^{2}\right)$. LAI also varied significantly among families $(P<0.0001)$ from 2.63 for Da4 to 0.62 for $\mathrm{Ng} 11$ (Fig. 3b). Between families, stem volume index and crown area index also differed significantly $(P=0.0135$ and $P<0.0001$, respectively) greatest in $\mathrm{Ng} 25\left(35.8 \mathrm{dm}^{3}\right)$ and $\mathrm{K} 4\left(36.7 \mathrm{~m}^{2}\right)$, respectively. 
K16 displayed both lower crown area index $\left(19.2 \mathrm{~m}^{2}\right)$ and stem volume index $\left(3.06 \mathrm{dm}^{3}\right)$ (Fig. 3c, d).

\section{Gum yield variation}

Gum yield was significantly affected by provenance $(P=0.0002)$ and families $(P<0.0001)$. Daiba the smallest of the provenances, had significantly lower gum yield of $329.5 \mathrm{~g}$ (Table 2). Between families, Dia27 was the best gum producer with $965.7 \mathrm{~g}$ while Da20 was the lowest producer at $296.1 \mathrm{~g}$ (Fig. 3e). Gum yield was positively correlated with stem volume index and crown area index (Fig. 4) which explained $11 \%(P<0.0001)$ and $10 \%(P<0.0001)$ of gum variation, respectively.

\section{Carbon isotope composition $\left(\delta^{13} \mathrm{C}\right)$ and plant ploidy effects}

Ngane had significantly higher foliar $\delta^{13} \mathrm{C}(-27.03 \%$ ) than the other provenances which did not differ statistically (Table 2). Significant difference in carbon isotope composition were also found among families $(P=0.0137)$. $\mathrm{Ng} 26$ displayed the highest value $(-26.51 \%$ ) , and $\mathrm{K} 21(-31.26 \%$ ) the lowest (Fig. 3f). A significant difference $(P<0.0001)$ in foliar $\delta^{13} \mathrm{C}$ between diploids $(-27.91 \%$ ) and polyploids $(-27.12 \%$ ) was found (Fig. 5). However, within provenances, the effect of ploidy was not significant and $P$ values varied between 0.6855 for Daiba and 0.0683 for Kidira.

\section{Discussion}

This study revealed that provenances and families of Senegalia senegal differed in their relative responses to assessed physiological traits. The low, but statistically significant amount of variation between and within provenances confirms that differentiation exists at the genetic level. To meet the objectives of assessing variation among and within Senegalia senegal provenances of uniform age and common growth conditions, we used partial variance components analysis so that data are balanced (Khattree and Naik 1990; Searle et al. 1992). This approach is useful to better understand inter and intra genetic variation, which

(a)

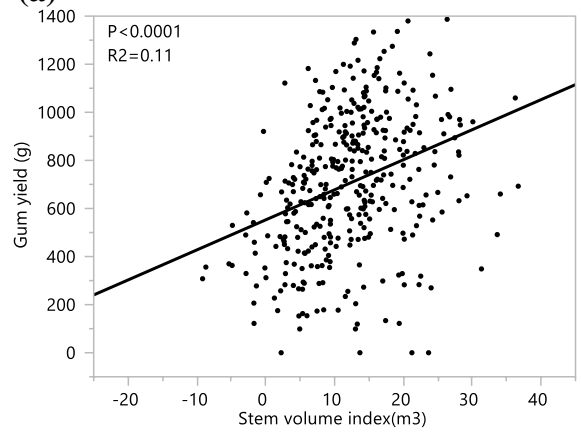

(b)

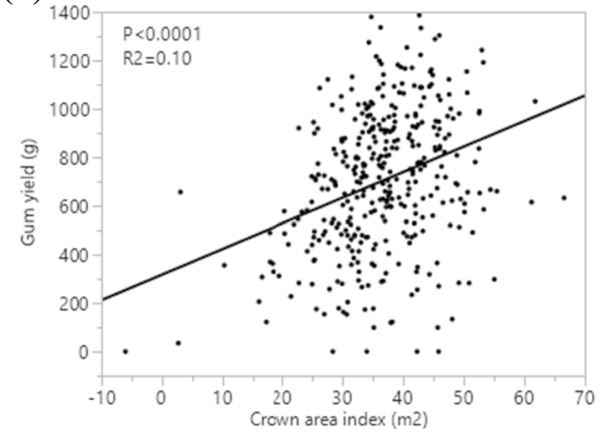

Fig. 4 Relationship between gum yield and stem volume index (a) and crown area index (b) 


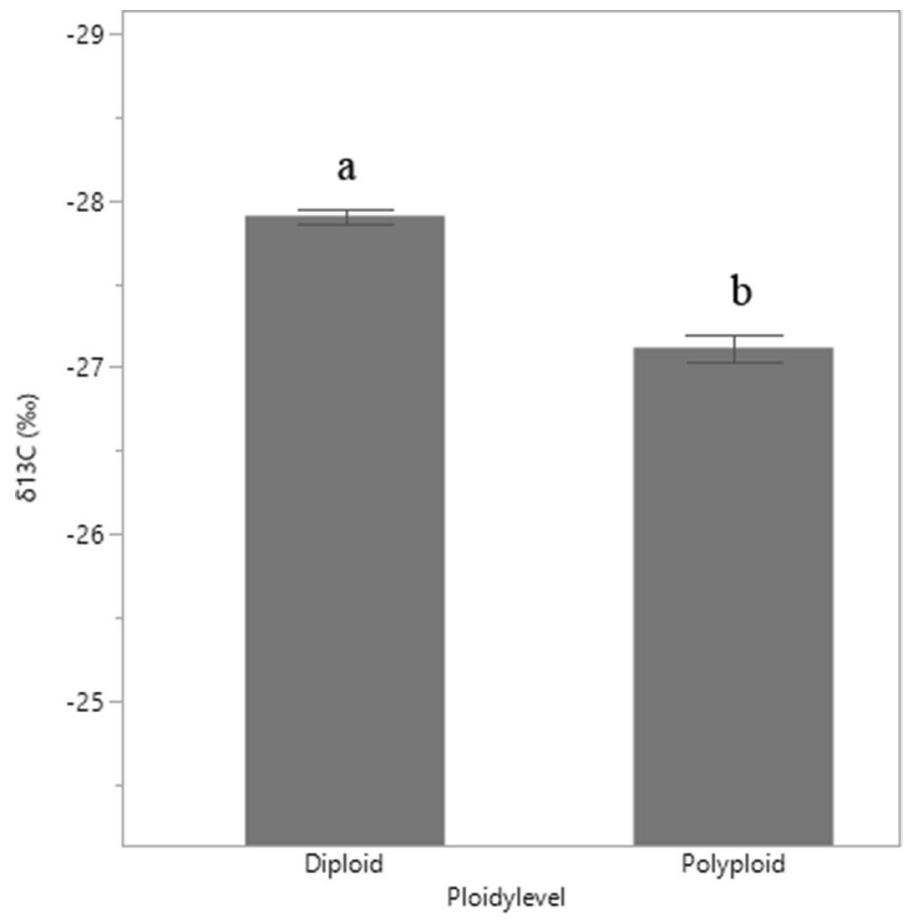

Fig. $5 \delta^{13} \mathrm{C}$ variation between Senegalai senegal diploids and polyploids

is critical in tree selection (Bowman 1972). Despite low genetic variation, most variability occurred within provenance rather than between provenances for tree survival rate, gum yield and crown area index. However, the large variation among blocks within the trial implies a great environmental effect on leaf area index expression. Significant differences observed between provenances (Table 2) and families (Fig. 3) on gum yield suggests that it may be possible to identify and select superior genotypes.

We observed significant differences in tree survival rate which is an indicator of performance and adaptability that can be used for provenances evaluation (Raebild et al. 2002; Weber et al. 2015). In a long-term field study on Prosopis africana, Weber et al. (2015) found that provenances from areas with low rainfall had the best tree survival rate. We found similar patterns. The best survival rate was recorded for Diamenar (46.7\%) which originated from the drier area (284 $\mathrm{mm}$ of rainfall) in comparison with the rest of the provenances. Provenance variability in gum was also related to provenance origin. Ngane, from a relatively wetter area $(712 \mathrm{~mm}$ of rainfall) yielded more gum per tree (567.63 g and $409.05 \mathrm{~g}$ vs. an average of $414.39 \mathrm{~g}$ and $330.29 \mathrm{~g}$ for all others, respectively). This finding is similar to what was reported in earlier studies (Raddad and Luukkanen 2006; Harmand et al. 2012). Unanaonwi and Bada (2012) and Lovelesh et al (2018) also reported a positive effect of tree girth on gum yield from Senegalia senegal and Cormiphora wightii, respectively. These finding are consistent with our result reporting a positive relationship between gum yield and stem volume index. Traits such as tree diameter and other related growth parameters require careful consideration during tree selection as they are positively correlated with gum yield. However, 
despite lower survival rate (34.3\%), Ngane, because of its higher gum yield per tree, had an annual gum yield per hectare as high as Diamenar (data not shown) which displayed the highest survival rate $(46.7 \%)$. This demonstrates the importance of selecting for both high survival rate and high gum yield as both will impact overall gum productivity. For example, gum yield in a stand can be improved by increasing tree survival rate alone. Thus, improving long-term survival of Senegalia senegal is an area of research that has to be investigated in order to maximize gum yield potential. In the Sahelian and Sudanian zones of West Africa, natural ranges of Senegealia senegal are becoming increasingly hotter and drier (Shepard 2019). One way to improve survival is to use provenances from drier zones because they probably have a greater root/shoot weight ratio and therefore could extract soil moisture at greater soil depths (Weber et al. 2015). Furthermore, improving survival of Senegalia senegal with better management such as weed control, protecting seedlings from browsing animals, and soil amendments should be investigated as well. For example, the positive correlation between soil $\mathrm{pH}$ and tree survival rate found in this study (Fig. 2) demonstrates the influence of soil conditions on tree survival. Best survival occurred at soil $\mathrm{pH}$ close to 7.0. This finding brings into question Von Maydell (1986) who reported that Senegalia senegal is adapted to a wide range of soil $\mathrm{pH}$. Thus, further studies testing provenance responses to different soil $\mathrm{pH}$ levels would be of great importance.

The negative correlation between gum yield and WUE reported recently by Raddad and Luukkanen (2006) and Gray et al. (2013) was not confirmed in this study. In contrast, a significant $(P=0.0302)$ positive relationship between foliar $\delta^{13} \mathrm{C}$ and gum yield was found (data not shown), but the coefficient of determination was very small (only $2 \%$ ). However, WUE is critically important to investigate in tree selection for species such as Senegalia senegal which grows in dryland ecosystems with frequent and severe drought events (De Almeida Silva et al. 2012). Significant variations in isotopic composition values also were found among provenances. This result is supported by previous research which reported differences of foliar $\delta^{13} \mathrm{C}$ between species (Farquhar et al. 1989; Garten and Taylor 1992; Zhang and Cregg 1996; Gebrekirstos et al. 2011) in general and especially among Senegalia senegal provenances (Raddad and Lukkannen 2006; Gray et al. 2013). A higher WUE (as expressed by higher carbon isotope composition) was observed in Ngane (Table 2), meaning that Ngane may have a higher net photosynthetic rate, a lower transpiration rate or both (Ehleringer et al. 1993). This finding may also be related to the greater stem volume index and crown area index which were determined as proxies of relative growth rate and leaf area, respectively. The foliar $\delta^{13} \mathrm{C}$ value of Ngane provenance $(-27.03 \%$ ) was substantially higher than what were reported by similar studies, where foliar $\delta^{13} \mathrm{C}$ between provenances varied from -28.96 to $-28.50 \%$ (Raddad and Luukkanen 2006) and from ca. -31 to ca. $-28.50 \%$ (Gray et al. 2013). This may explain the greater growth rate and attributes in Ngane (Sarr et al. 2017).

Our results showed that despite significant association between ploidy and WUE, only $15 \%$ of isotope compositions could be explained by ploidy level variation. This suggests that other factors are involved on Senegalia senegal WUE. With the exception of Kidira, within provenance ploidy effect on foliar $\delta^{13} \mathrm{C}$ was not significant at $10 \%$ significant level. The effective implication of ploidy level in Senegalia senegal response to environment needs to be further investigated. A recent study examining the relationship between polyploidy and leaf traits in Brassica species supports that physiological consequences of polyploidy remain unclear (Baker et al. 2017). We suggest that Ngane and Diamenar, predominantly polyploid and diploid respectively (Diallo et al. 2015) may be promising sources to 
investigate in terms of gum yield and drought adaptation to improve gum Arabic production in Senegal.

WUE based on foliar $\delta^{13} \mathrm{C}$ will likely change with soil water availability and sampling date (Blum 2005, 2009; Gebrekirstos et al. 2011). Gebrekirstos et al. (2011) revealed a contrasting water use strategy in Senegalia senegal between the rainy and dry seasons. We did not explore $\delta^{13} \mathrm{C}$ during the growing season, but based on earlier findings on Senegalia senegal, plants displaying higher or lower WUE under drought, may exhibit lower or higher WUE, respectively throughout the growing season (Gebrekistos et al. 2011; Gray et al. 2013). Based on this assumption, it could be that Ngane would exhibit higher water use strategies (lower WUE) during the growing season as well, which will need to be investigated in future studies.

The LAI was assessed in late October, which corresponds to the beginning of the dry season in Senegal. At that period, deciduous trees such as Senegalia senegal already start shedding leaves to minimize water loss in response to water stress. Nonetheless, our results indicated a significant difference of LAI between Ngane and Daiba and Diamenar (Table 2). The different observed patterns of LAI between provenances may reflect different responses to environmental stress such as water limitation. The lower LAI in Ngane could be related to earlier leaf shedding. The seasonal patterns of LAI have been earlier observed in cowpea (Anyia and Herzog 2003), some evergreen forest trees (Doughty and Goulden 2008) and Brassica juncea (Singh et al. 2009). However, despite the positive correlation between LAI and WUE revealed by recent studies (Liu et al. 2015; Xue et al. 2015) Ngane with lower LAI tended to have higher WUE. This result confirms Jones (1985) who showed that plants with lower LAI tended to increase their WUE. A more recent study completed in California ecosystems also supports that conclusion (Malone et al. 2016). Furthermore, whole tree transpiration is generally known to increase with LAI (Bréda and Granier 1996; Cregg et al. 2000) and therefore WUE and total leaf area are important parameters to consider when examining plant adaptations to water stress.

\section{Conclusion}

This study emphasizes the importance of genotype-based tree selection for tree improvement program of Senegalia senegal. Although improving drought tolerance is a good option to improve tree survival in dryland ecosystems, a key result from this study is that soil $\mathrm{pH}$ affects tree survival rate and accordingly gum yield. Based on our findings, Daiba provenance does not appear to be a good source for Dahra and likely the sylvopastoral zone in Senegal. Ngane, Diamenar, and Kidira produced consistently more gum than Daiba. But, Ngane and Diamenar have been suggested as better performing sources according to their gum productivity and drought tolerance strategies. Thus, identification and selection of high-performing sources in terms of gum yield and traits associated with drought tolerance might be a starting point for improvement of the gum arabic production in Senegal. Ploidy level may influence WUE, but further studies are still needed to clarify the relationship. Investigation of sylvicultural management practices aimed at improving seedling survival and growth of the trees is also important for optimizing gum production of a stand.

Acknowledgements We are grateful to Centre National de Recherche Forestière for the logistical support provided during the fieldwork. We thank Mrs Momar Wade and Ibra Padane for their support in collecting 
data, Dr Marieme Fall Ba and Dr Mamadou Ousseynou Ly for their help to conduct soil analysis. A big thank to Mr Andy Laviner for his help on using the LAI 2200, and Mr David Mitchem to conduct isotope analysis of leaves. This article is made possible in part by the generous support of the American people through the United States Agency for International Development (USAID) as part of Feed the Future, the U.S. Government's global hunger and food security initiative, under the terms of Contract No. AID685-A-00-10-00194-00 (USAID/Education and Research in Agriculture). The contents are the responsibility of the author(s) and do not necessarily reflect the views of USAID or the United States Government.

\section{Compliance with ethical standards}

Conflict of interest The authors declare that they have no conflict of interest.

Open Access This article is licensed under a Creative Commons Attribution 4.0 International License, which permits use, sharing, adaptation, distribution and reproduction in any medium or format, as long as you give appropriate credit to the original author(s) and the source, provide a link to the Creative Commons licence, and indicate if changes were made. The images or other third party material in this article are included in the article's Creative Commons licence, unless indicated otherwise in a credit line to the material. If material is not included in the article's Creative Commons licence and your intended use is not permitted by statutory regulation or exceeds the permitted use, you will need to obtain permission directly from the copyright holder. To view a copy of this licence, visit http://creativecommons.org/licenses/by/4.0/.

\section{References}

Adam IM, Ballal ME, El Kamal MF (2013) Effect of grass density and date of tapping on Acacia senegal gum yield in north kordofan state, Sudan. J For Res 24:169-172

Anyia AO, Herzog H (2003) Water use efficiency, leaf area and leaf gas exchange of cowpeas under mid-season drought. Eur J Agron 30:1-13

Bacelar EA, Santos DL, Moutinho-Pereira JM, Lopes JI, Gonçalves BC, Ferreira TC, Correia CM (2007) Physiological behavior, oxidative damage and antioxidative protection of olive trees grown under different irrigation regimes. Plant Soil 292:1-12

Baker RL, Yarkhunova Y, Vidal K, Ewers BE, Weinig C (2017) Polyploidy and the relationship between leaf structure and function: implications for correlated evolution of anatomy, morphology, and physiology in Brassica. BMC Plant Biol 17(1):3

Barbier EB (1992) Rehabilitating gum arabic systems in sudan: economic and environmental implications. Environ Resour Econ 2:341-358

Blum A (2005) Drought resistance, water-use efficiency, and yield potential—Are they compatible, dissonant, or mutually exclusive? Aust J Agric Res 56:11-59

Blum A (2009) Effective use of water (EUW) and not water-use efficiency (WUE) is the target of crop yield improvement under drought stress. Field Crop Res 112:119-123

Bowman JC (1972) Genotypexenvironment interactions. In: Annales de genetique et de selection animale. EDP Science 4, pp 117-123

Bradley D, Grainger A (2004) Social resilience as a controlling influence on desertification in Senegal. Land Degrad Dev 15(5):451-470

Brandt M, Grau T, Mbow C, Samimi C (2014) Modeling soil and woody vegetation in the senegalese sahel in the context of environmental change. Land 3:770-792

Bréda N, Granier A (1996) Intra- and interannual variations of transpiration, leaf area index and radial growth of a sessile oak stand (Quercus Petraea). Annales des Sciences Forestières 53:521-536

Chikamai BN, Odera JA (2002) Commercial plant gums and gum resins in Kenya. Sources of Alternative Livelihood and Economic Development in the Drylands of Kenya. Executive Print. Nairobi-Kenya

Craig H (1953) The geochemistry of the stable carbon isotopes. Geochim Cosmochim Acta 3:53-92

Cregg BM, Olivas-García JM, Hennessey TC (2000) Provenance variation in carbon isotope discrimination of mature ponderosa pine trees at two locations in the great plains. Can J For Res 30:428-439

De Almeida Silva M, Dos Santos CM, Labate CA, Guidetti-Gonzalez S, De Santana Borges J, Ferreira LC, Fritsche-Neto R (2012) Breeding for water use efficiency. In: Plant breeding for abiotic stress tolerance. Springer, Berlin, Heidelberg, pp 87-102

Diallo I (1994) Etude de quelques aspects de la biology de la reproduction de Acacia senegal (L.) Willd. Memoire de Confirmation, Direction de Recherches sur les Productions Forestières, p 38 
Diallo AM, Nielsen LR, Hansen JK, Ræbild A, Kjær ED (2015) Study of Quantitative Genetics of Gum Arabic Production Complicated by Variability in Ploidy Level of Acacia Senegal (L.) Willd. Tree Genet. Genomes. 11:1-13

Diallo AM, Nielsen LR, Kjær ED, Petersen KK, Ræbild A (2016) Polyploidy can confer superiority to West African Acacia Senegal (L.) willd trees. Front Plant Sci 7:8-21

Dione M, Vassal J (1998) Gommose et rythme de production gommière chez Acacia senegal (L.) Wild. In: Campa C (eds.), L'acacia au Sénégal. IRD France, pp 123-134

Doughty CE, Goulden ML (2008) Seasonal patterns of tropical forest leaf area index and $\mathrm{CO}_{2}$ exchange. J Geophys Res Biogeosci 113(G1):G00B06

Ehleringer JR, Hall AE, Farquhar GD (1993) Stable isotopes and plant carbon/water relations. Academic Press, San Diego

Farquhar GD, Ehleringer JR, Hubick KT (1989) Carbon isotope discrimination and photosynthesis. Annu Rev Plant Biol 40:503-537

Garten CT, Taylor GE (1992) Foliar $813 \mathrm{C}$ within a temperate deciduous forest: spatial, temporal, and species sources of variation. Oecologia 90:1-7

Gebrekirstos A, Van Noordwijk M, Neufeldt H, Mitlöhner R (2011) Relationships of stable carbon isotopes, plant water potential and growth: an approach to asses water use efficiency and growth strategies of dry land agroforestry species. Trees 25:95-102

Gonzalez P (1997) Dynamics of biodiversity and human carrying capacity in the Senegal Sahel. Ph.D. Dissertation, University of California, Berkeley, p 427

Göttsche FM, Olesen FS, Trigo IF, Bork-Unkelbach A, Martin MA (2016) Long term validation of land surface temperature retrieved from MSG/SEVIRI with continuous in-situ measurements in Africa. Remote Sens 8:4-10

Gray A, Odee D, Cavers S, Wilson J, Telford A, Grant F, Diouf M, Ochieng J, Grant H, Stott A (2013) Does geographic origin dictate ecological strategies in Acacia senegal (L.) willd? Evidence from carbon and nitrogen stable isotopes. Plant Soil 369:479-496

Greer BT, Still C, Cullinan GL, Brooks JR, Meinzer FC (2017) Polyploidy influences plant-environment interactions in quaking aspen (Populus tremuloides Michx). Tree Physiol 38(4):630-640

Harmand JM, Ntoupka M, Mathieu B, Forkong Njiti C, Tapsou JM, Bois JC, Thaler P, Peltier R (2012) Gum arabic production in Acacia senegal plantations in the Sudanian zone of Cameroon: effects of climate, soil, tapping date and tree provenance. Bois forêts tropiques 311:21-33

Husch B, Beers TW, Kershaw JA (2003) Forest mensuration, 4th edn. Wiley, Hoboken, p 443

Jones HG (1985) Partitioning stomatal and non-stomatal limitations to photosynthesis. Plant Cell Environ 8:95-104

Josiah CC, George DO, Eleazar OM, Nyamu WF (2008) Genetic diversity in Kenyan populations of Acacia senegal (L.) willd revealed by combined RAPD and ISSR markers. Afr J Biotechnol 7(14):2333-2340

Khattree R, Naik DN (1990) Optimum tests for random effects in unbalanced nested designs. Statistics 21:163-168

Lawesson JE (1995) Studies of woody flora and vegetation in Senegal. In: Cahiers d'outre-mer. No. 201 - 51e année, Janvier-mars 1998. pp 109-110

Liu Y, Jingfeng X, Weimin JYZ, Shaoqiang WXW (2015) Water use efficiency of China's terrestrial ecosystems and responses to drought. Sci Rep 5:13799

Lovelesh SS, Rajput SK, Rathore TR, Tomar UK (2018) Non-destructive harvesting of oleo-gum resin in Commiphora wightii (Arnott) Bhandari-a critically endangered plant. Ind Crops Prod 113:259-265

Maherali H, Walden AE, Husband BC (2009) Genome duplication and the evolution of physiological responses to water stress. New Phytol 184:721-731

Malone SL, Tulbure MG, Pérez-Luque AJ, Assal TJ, Bremer LL, Drucker DP, Hillis V, Varela S, Goulden ML (2016) Drought resistance across California ecosystems: evaluating changes in carbon dynamics using satellite imagery. Ecosphere 7:01-56

Mujawamariya G, D’Haese MFC (2012) In search for incentives to gum arabic collection and marketing in Senegal: interlocking gum trade with pre-finances from traders. For Policy Econ 25:72-82

Mujawamariya G, Burger K, D'Haese M (2012) Quality of gum arabic in Senegal: linking the laboratory research to the field assessment. Q J Int Agric 51(4):357-383

Poupon H (1976) La biomasse et l'évolution de sa répartition au cours de la croissance d'Acacia senegal dans une savane sahélienne (Sénégal). Bois For Trop 166:23-38

Raddad EY, Luukkanen O (2006) Adaptive genetic variation in water-use efficiency and gum yield in Acacia senegal provenances grown on clay soil in the Blue Nile Region, Sudan. For Ecol Manag 226:219-229

Raddad EY, Luukkanen O, Salih AA, Kaarakka V, Elfadl MA (2006) Productivity and nutrient cycling in young Acacia senegal farming systems on vertisol in the Blue Nile Region, Sudan. Agrofor Syst 68:193-207 
Ræbild A, Hansen CP, Kjaer ED (2002) Statistical analysis of data from provenance trials. Danida Forest Seed Center

Rivero RM, Kojima M, Gepstein A, Sakakibara H, Mittler R, Gepstein S, Blumwald E (2007) Delayed leaf senescence induces extreme drought tolerance in a flowering plant. Proc Natl Acad Sci USA 104:19631-19636

Sarr MS, Seiler JR, Sullivan J (2017) Growth and physiology of Senegalia senegal (L.) Britton seedlings as influenced by seed origin and salinity and fertility treatments. Forests $8: 388$

Searle SR, Casella G, McCulloch CE (1992) Variance components. Wiley, Hoboken

Segraves K, Anneberg T (2016) Species interactions and plant polyploidy. Am J Bot 103:1326-1335

Shepard D (2019) Global warming: severe consequences for Africa: new report projects greater temperature increases. Afr Renew 32(3):34

Singh M, Chauhan JS, Meena SS (2009). Drought induce changes in water use efficiency and other morphophysiological characters in Indian mustard (Brassica juncea L.). 16th Australian Research Assembly on Brassicas, Ballarat Victoria, pp 1-5

Unanaonwi OE, Bada O (2012) Effect of tree height and girth on gum yield of Acacia senegal L. In savanna woodland of Nigeria

Von Maydell HJ, (1986) Trees and shrubs of the Sahel, their characteristics and uses. Deutsche Gesellschaft fuer Technische Zusammenarbeit (GTZ), Eschborn, Germany

Weber JC, Sotelo Montes C, Kalinganire A, Abasse T, Larwanou M (2015) Genetic variation and clines in growth and survival of Prosopis africana from Burkina Faso and Niger: comparing results and conclusions from a nursery test and a long-term field test in Niger. Euphytica 205(3):809-821

Wekesa C, Makenzi PM, Chikamai BN, Luvanda AM, Muga MO (2010) Traditional ecological knowledge associated with Acacia senegal (Gum Arabic Tree) management and gum arabic production in northern Kenya. Int For Rev 12:240-246

Xue BL, Guo Q, Otto A, Xiao J, Tao S, Li L (2015) Global patterns, trends, and drivers of water use efficiency from 2000 to 2013. Ecosphere 6:174

Zhang JW, Cregg BM (1996) Variation in stable carbon isotope discrimination among and within exotic conifer species grown in eastern Nebraska, USA. For Ecol Manag 83:181-187

Publisher's Note Springer Nature remains neutral with regard to jurisdictional claims in published maps and institutional affiliations.

\section{Authors and Affiliations}

\section{Mame S. Sarr ${ }^{1}$ (D) John R. Seiler ${ }^{2} \cdot$ Jay Sullivan $^{2} \cdot$ Adja M. Diallo $^{1} \cdot$ Brian D. Strahm² $^{2}$}

1 Centre National de Recherche Forestière, Institut Sénégalais de Recherche Agricole, Dakar, Sénégal

2 Department of Forest Resources and Environmental Conservation, Virginia Polytechnic Institute and State University, Blacksburg, VA 24061, USA 